Received: November 13, 2006

Accepted after revision: August 1, 2007

Published online: January 8, 2008

\title{
The IGF Axis and Placental Function
}

\author{
A Mini Review \\ Karen Forbes Melissa Westwood \\ Maternal and Foetal Health Research Group, University of Manchester, St Mary's Hospital, Manchester, UK
}

\section{Key Words}

Placenta · Proliferation • Differentiation • Migration • Apoptosis $\cdot$ Insulin-like growth factor $\cdot$ Insulin-like growth factor binding protein $\cdot \mathrm{PI} 3 \mathrm{~K} \cdot$ Mitogen-activated protein kinase

\begin{abstract}
It is well known that the insulin-like growth factor (IGF) axis is an important regulator of foetal growth and in recent years, it has been suggested that the ligands IGF-I and IGF-II may, in part, mediate this effect by promoting proper placental development and function. In other tissues, IGF effects on metabolism, proliferation and differentiation are primarily mediated via IGF binding protein-regulated interaction of IGFs with the type 1 IGF receptor and therefore here, we review the placental expression and postulated role, of each of the IGF axis components and discuss the cellular mechanisms through which these effects are exerted.
\end{abstract}

Copyright $\odot 2008$ S. Karger AG, Basel

\section{The IGF Axis}

The insulin-like growth factors, IGF-I and IGF-II are two small, highly homologous single chain polypeptides with similarities to pro-insulin [1]. Their actions are mediated by binding to the type-1 IGF receptor (IGF1R) although IGF-II and (to a lesser extent) IGF-I can also bind to the type-2 IGF/mannose-6-phosphate receptor
(IGF2R/M6PR) or the insulin receptor; ligand access to these receptors is regulated by a family of binding proteins termed IGF-binding proteins (IGFBPs) 1-6. The IGFBPs serve many functions, e.g. they prolong the halflife of IGF and provide a circulating storage reservoir for IGF. Most of the IGF in the circulation exists in a $150-\mathrm{kDa}$ ternary complex consisting of IGFBP-3 and the acid labile subunit (ALS); when this complex dissociates, the IGFs form smaller, binary complexes with the other IGFBPs, which then transport IGF cross the endothelium to target tissues [1]. The importance of circulating IGF, which is mainly produced by the liver [1], for body growth has recently been questioned due to data from animals (liver specific IGF-I gene knockout [2] and ALS gene knockout [3]) with reduced serum IGF-I levels which highlighted the key role of autocrine/paracrine IGF for tissue growth. All extrahepatic tissues also produce a range of IGFBPs and their role at these sites is to modulate IGF actions.

The IGFBPs have a higher affinity for IGFs than the IGF receptors [4] and can therefore sequester IGFs to function as IGF inhibitors. However, in some circumstances, particularly pregnancy, the post-translational modification of IGFBPs (e.g. phosphorylation and proteolysis) is altered so that IGFBP affinity for IGF is reduced and therefore, bioavailability is increased. Interestingly, several IGFBPs, particularly IGFBP-3 and IGFBP-5, have also been shown to have IGF-independent actions; however the mechanisms by which these effects are regulated are not fully understood and so will not be discussed further.

\section{KARGER \\ Fax +41613061234 \\ E-Mail karger@karger.ch}

www.karger.com
(C) 2008 S. Karger AG, Basel

0301-0163/08/0693-0129\$24.50/0

Accessible online at:

www.karger.com/hre
Melissa Westwood

Maternal and Fetal Health Research Group, University of Manchester

St Mary's Hospital, Hathersage Road, Manchester M13 0JH (UK)

Tel. +44161276 5461, Fax +44161276 6134

E-Mail melissa.westwood@manchester.ac.uk 
In the 50 or so years since the discovery of the IGFs, it has become clear that these hormones are involved in mediating growth, differentiation, survival, and metabolism in almost every organ of the body [4] and in recent years, numerous studies have highlighted the importance of these actions for foetal growth and development.

\section{The IGF Axis Controls Foetal Growth}

The first suggestion of IGF involvement in regulating foetal growth came from clinical studies reporting aberrant IGF levels in conditions associated with abnormal foetal growth; measurement of IGF levels in cord blood from healthy newborns demonstrated that birth weight is positively correlated with IGF-I levels $[5,6]$ and so levels are low in small-for-gestational-age (SGA) infants and enhanced in large-for-gestational-age (LGA) babies [7]. Subsequent studies using transgenic mice confirmed these clinical observations by demonstrating that mutation of the gene encoding either IGF-I or IGF-II results in offspring that are approximately $40 \%$ smaller than their wild-type littermates [8].

Disordered foetal growth may also be the consequence of abnormal IGFBP levels as there are numerous reports of increased maternal IGFBP-1 levels in pregnancy complications such as intrauterine growth restriction and pre-eclampsia [5]. This is supported by studies in transgenic mice which have elevated levels of circulating IGFBP-1; in these animals there was no change in the level of IGF-I yet foetal growth restriction was observed thereby demonstrating that an elevated level of circulating IGFBP-1 is sufficient to cause alterations in foetal growth [9]. There are conflicting reports about the role of IGFBP-3 in regulating foetal growth. In many studies IGFBP-3 levels correlate positively with birth weight in both normal and complicated pregnancies [6,7]; however, one study reported elevated IGFBP-3 levels in SGA infants [10]. Similarly, in offspring of mice overexpressing the human IGFBP-3 gene a significant reduction in birth weight was reported [11]. Interestingly, both IGFBP1 and IGFBP-3 are produced in abundance by the maternal-foetal interface and during pregnancy, their posttranslational modification at this site should result in decreased affinity for IGF-I, therefore it is possible that abnormalities in this process could also modulate intrauterine growth.

IGFs induce their effects on cellular proliferation, differentiation and survival primarily by binding to and ac- tivating the type 1 IGF receptor (IGF1R). Activation of the receptor results in autophosphorylation of tyrosine residues in the intracellular $\beta$-subunits and subsequent activation of downstream signalling pathways [4]. IGF receptor abnormalities can also impact on foetal growth and in particular, the consequence of disrupted IGF1R function was highlighted in a recent study reporting severe foetal growth restriction in two infants with a heterozygous missense mutation in the IGF1R gene [12]. Further evidence for the importance of the IGF1R in mediating IGF effects on foetal growth comes from the demonstration that igfrl null mice have a much more severe phenotype than the IGF-I or -II knockout animals as birth weight is reduced by approximately $60 \%$ when compared to normal littermates [8].

The type-2 IGF receptor (IGF2R) does not contain tyrosine kinase activity or an auto-phosphorylation site and therefore it has been suggested that the primary function of this receptor is to clear IGF-II from the circulation; this is supported by studies demonstrating that mice lacking the IGF2/M6PR have much greater birth weights than wild-type littermates $[8,13]$ and highlights the importance of IGF-II in regulating foetal growth.

\section{The IGF Axis in the Placenta}

It is well known that reduced foetal growth is associated with abnormal placental development [14] and therefore it has been suggested that the IGFs may influence foetal growth through a role in promoting normal placental development and function; this is supported by the fact that reduced foetal size in IGF-II knockout mice is accompanied by changes in the morphological features and also the size of the placentas in these animals $[8,15]$ and moreover, the observation that in mice lacking the placental specific transcript of the igf2 gene (P0) placental growth is reduced and subsequently, this translates into a reduction in foetal size [16]. These data therefore demonstrate the importance of understanding how the IGF axis regulates placental development and function.

\section{The Human Placenta}

In chorionic villi of the human placenta (fig. 1), cytotrophoblasts proliferate and differentiate into one of two subtypes, extravillous trophoblasts which migrate into the maternal decidualised endometrium and invade spiral arteries thereby establishing a supply of oxygen to the placenta and fetus; or syncytiotrophoblast, a multinucle- 


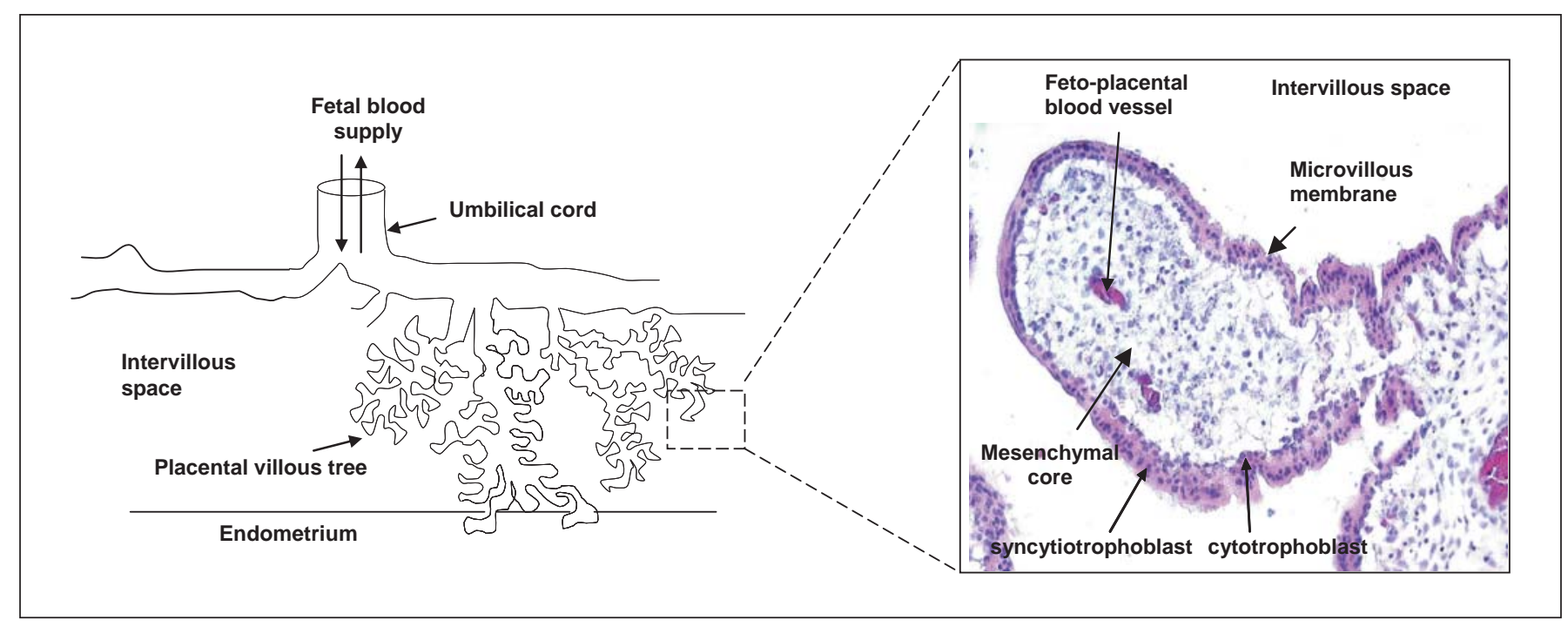

Fig. 1. Structure of 1st-trimester placental villous. Freshly isolated first trimester placenta was stained with haematoxylin and eosin. Arrows indicate the villous mesynchymal core which is surrounded by a continuous layer of cytotrophoblasts, which in turn are covered by a multinucleated syncytiotrophoblast. The syncytiotrophoblast acts both as a protective barrier and as a membrane for exchange of nutrients and gas between the mother and the fetus (via the intervillous space).

ated epithelium which acts both as a nutrient and gas exchange membrane and also a protective barrier [17]. Below the cytotrophoblasts lies the mesenchymal core (also termed the villous core or villous stroma) of the placenta which contains placental capillaries and various cells including fibroblasts [17]. The syncytiotrophoblast layer has no transcriptional activity and hence during pregnancy, it is maintained by the continual proliferation and differentiation of cytotrophoblasts. Abnormalities in the regulation of placental cell turnover have been reported in pregnancy complications such as pre-eclampsia and intrauterine growth restriction (IUGR) and although little is known about the processes that regulate cell turnover in the placenta, it is clear that IGFs have a role.

\section{Expression and Function of the IGF Axis in the \\ Placenta \\ IGFs}

IGF-I and IGF-II are present in almost all cell types of the placenta from as early as 6 weeks' gestation [18] (table 1) and they appear to be involved in almost all aspects of placental development and function. Recent work utilizing anti-sense adenoviral constructs for IGF-I and IGF-II demonstrate that they both enhance the proliferation and survival of placental fibroblast [19]; further in- dication of a survival role for IGFs in the placenta comes from the finding that IGF-I can also rescue both trophoblast and placental fibroblasts from apoptosis $[19,20]$.

A role for IGFs in regulating trophoblast migration was first suggested by data from monolayer wounding [21] and trans-Matrigel barrier assays [22] which demonstrated that both ligands can enhance trophoblast migration and invasion $[23,24]$. Interestingly, although IGFs influence the migration of extravillous trophoblasts they have no effect on extravillous mitogenesis [22]. More recently, a study investigating processing of pro-IGF-II to its active form reported that in IUGR, the levels of proIGF-II are increased [25] and furthermore, aberrant processing of pro-IGF-II results in reduced levels of trophoblast migration [25].

The ability of cytotrophoblasts to differentiate into either syncytiotrophoblast or extravillous trophoblasts is essential for successful placental development. IGF-I is known to regulate both the differentiation of cytotrophoblasts into syncytiotrophoblast $[26,27]$ and into extravillous cells $[23,24]$, but there are no reports to implicate IGF-II in regulating placental cell differentiation. However, there are data to suggest that IGF-II may have a role in regulating nutrient exchange. In mice with placental specific knockdown of IGF-II the placentae have a significantly reduced diffusional exchange surface area, the 
Table 1. Expression of components of the IGF axis at the maternal fetal interface

\begin{tabular}{|c|c|c|}
\hline $\begin{array}{l}\text { Component } \\
\text { of IGF axis }\end{array}$ & Expression at maternal-fetal interface & Author, year \\
\hline IGF-I & villous cytotrophoblast; extravillous trophoblast; microvillous membrane; decidua & Han et al., 1996 \\
\hline IGF-II & $\begin{array}{l}\text { chorionic plate; chorionic mesoderm; cytotrophoblast; extravillous trophoblast; } \\
\text { amnion and chorion leave }\end{array}$ & Han et al., 1996 \\
\hline IGFBP-1 & endometrial stromal cells and decidualised stroma & Han et al., 1996 \\
\hline IGFBP-2 & decidua & Han et al., 1996 \\
\hline IGFBP-3 & decidua; extravillous trophoblast; amnion and chorion leave; villous core & Han et al., 1996 \\
\hline IGFBP-4 & decidua; villous core & Han et al., 1996 \\
\hline IGFBP-5 & decidua; villous core & Han et al., 1996 \\
\hline IGFBP-6 & decidua & Han et al., 1996 \\
\hline IGF1R & syncytiotrophoblast; cytotrophoblast; microvillous membrane; villous core & $\begin{array}{l}\text { Murata et al., 1994; Fang et al., } \\
\text { 1997; Holmes et al., } 1999\end{array}$ \\
\hline IGF2/M6PR & microvillous membrane & Fang et al., 1997 \\
\hline
\end{tabular}

barrier thickness is enhanced and they have reduced permeability for nutrients, although interestingly, the amino transport activity in these mice is only abolished when foetal IGF-II is removed [28, 29]. Similarly in guinea pigs, enhanced maternal IGF-II increases the total surface area of placenta for nutrient exchange by $39 \%$ [30]. In contrast, IGF-I did not affect the surface area of the placenta, but appeared to divert nutrients from mother to fetus. Further evidence supporting the role of IGFs in mediating nutrient transfer comes from in vitro studies, where in both cultured human primary trophoblast cells and in the BeWo choriocarcinoma cell line, physiological levels of IGF-I enhance amino acid uptake [31, 32].

Many studies have reported increased placental expression of IGF-I and IGF-II in IUGR pregnancies [33, 34] and, similarly, elevated levels of placental IGF-I and-II mRNA have been observed in a sheep model of IUGR [35]. These findings are somewhat surprising as, like in cord blood, a decrease in placental IGF levels might have been anticipated. Researchers suggest that placental transcription of these hormones is increased in an attempt to compensate for growth restriction $[33,36]$. Alternatively, transcription levels may be increased to overcome the inhibitory effect of the enhanced level of IGFBPs and/or number of IGF2R that are observed in IUGR pregnancies [37].

\section{IGFBPs}

Human placental cells do not express IGFBP-1; however, it is the most abundantly expressed binding protein in the decidualised endometrium [18]. Since IGFBP-1 has been found to associate with trophoblast [38] it is thought that IGFBP-1 released from the endometrium is involved in regulating the actions of IGFs in the placenta. The role of IGFBP-1 in the placenta, however, is controversial. It has been reported that IGFBP-1 can enhance both basal and IGF-II induced extravillous trophoblast migration $[21,22]$; however, others report that IGFBP-1 prevents trophoblast migration [39]. We have proposed that these conflicting results may be due to the post-translational modification of IGFBP-1.

In the circulation of non-pregnant women IGFBP-1 exists only in its phosphorylated state (p-IGFBP-1) and this isoform has a high affinity for IGFs. During pregnancy however, the phosphorylation status of IGFBP-1 changes; IGFBP-1 is dephosphorylated, presumably by placental alkaline phosphatase which is expressed by the syncytiotrophoblast, to non-phosphorylated and lesser phosphorylated isoforms (np-IGFBP-1) [40] that have reduced affinity for IGF-I. np-IGFBP-1, however, still has a similar affinity for IGF-II and instead it is the proteolytic cleavage of np-IGFBP-1 by matrix metalloproteases (MMPs) at the maternal-foetal interface that regulates its affinity for IGF-II [41]. Data supporting the hypothesis that post-translational modification of IGFBP-1 is important for its function in the placenta come from a study demonstrating that nutrient uptake by human trophoblast cells is affected by IGFBP-1 phosphorylation status [42]; npIGFBP-1 enhanced IGF-I amino acid uptake whilst phosphorylated IGFBP-1 inhibited this effect.

The predominant binding protein in placental tissue is IGFBP-3; it is expressed in high levels by trophoblast, fibroblasts of the villous stroma [43] and by the amnion and chorion leave of foetal membranes [18]. Relatively little is known about its role in the placenta; however, a 
study by Rogers et al. [43] which demonstrates that IGFBP-3 can inhibit IGF-stimulated mitogenesis of placental fibroblasts suggests that it functions to regulate IGF effects. Interestingly, the pregnancy-associated posttranslational modification of IGFBP-3 may also be mediated by the placenta as medium conditioned by both syncytiotrophoblast and extravillous trophoblast contains a disintegrin metalloproteinase which can cleave IGFBP-3 into fragments that have reduced affinity for IGF; as well as increasing bioavailability this process may be an important component of IGFBP-3 action in the placenta as in other tissues and cell systems IGFBP-3 fragments are thought to have IGF-independent biological activity [44].

\section{IGF Receptors}

The Type-I IGF Receptor. In the placenta, the IGF1R is localized to all cell types including the trophoblast, villous endothelium and the mesenchymal core $[45,46]$. Studies of transgenic mice lacking the IGF1R led to the hypothesis that a reduction in the number of placental IGF1R might be a contributing factor in pregnancies complicated by IUGR. An immunohistochemical study of placentas from normal and IUGR pregnancies found no difference in receptor localization or distribution [45], although a more recent study has demonstrated a significant reduction in IGF1R protein levels [47]. Interestingly, the reduction in IGF1R protein content in IUGR placentas was accompanied by impaired activation of intracellular signalling molecules and therefore the problems associated with IUGR may be caused by problems in the signalling events downstream of the IGF1R.

Hybrid Receptors. The type-I IGF receptor shares structural homology with the insulin receptor (IR), which is also expressed in the placenta as two isoforms, IR-A and IR-B, that differ by 12 amino acids. In foetal tissues the affinity of IR-A for IGF-II is similar to that of IGF1R [48] although the signalling cascades activated in response to IGF-II/IR-A binding are distinct from insulin-induced IR activation and are mainly mitogenic. Various studies have suggested that the level of IR in placentas complicated by IUGR or pre-eclampsia is comparable to that observed in normal pregnancies $[49,50]$, which may suggest that the placental response to insulin is not an important determinant of placental development/function and consequently foetal growth. However, analysis of mice containing null mutations in both the IGF-II and type 1 IGF receptor genes demonstrated that these animals were more severely growth restricted than mice in which only the IGF1R had been ablated [15], suggesting that IGF-II must medi- ate its affects, at least in part, by some other receptor, which may well be the insulin receptor.

Furthermore, many of the binding sites for IGF in the placenta are formed as hybrids of the IGF1R and the IR $[51,52]$. IGF-I can bind to these hybrid receptors with an affinity similar to that for the IGF1R $[53,54]$ and although the affinity of the hybrid receptors for insulin is far reduced compared to that for classic insulin receptors, at high concentrations insulin is also capable of activating both hybrid and IGF1Rs. Therefore, when studying IGF1R signalling in the placenta the potential involvement of insulin or IRs should be considered.

The Type-2 IGF Receptor. In the placenta, the IGF2R is expressed in the microvillous and plasma membranes of trophoblast [46] but can be proteolytically cleaved, resulting in release of a soluble form of the receptor which, when bound to IGF-II, results in degradation of IGF-II and inhibition of its mitogenic actions. Recently, it has been reported that the molar ratio of IGF-II to soluble IGF2R is significantly related to placental and birth weights [37] and therefore the role of IGF2R appears to be for preventing excessive IGF-II effects in the placenta. Alternatively, it may be that the IGF2R is involved in transducing extracellular signals. It has been suggested that IGF2R can couple to, and signal through, a Gi2 protein [55] and the recent study demonstrating that hCG increases trophoblast migration via the IGF2R [56] together with the finding that stimulation of human extravillous trophoblast migration by IGF-II is mediated by the IGF2R would support this hypothesis [57]. Nevertheless, this remains controversial and so only the signalling events mediated by the IGF1R will be discussed further.

\section{IGF1R Signalling Events in the Placenta}

\section{Kinases}

In other systems, ligand binding to the IGF1R results in activation of two main signalling cascades, the PI3K pathway or the mitogen-activated protein kinase (MAPK; also termed ERK1/2) pathway (fig. 2) [58]. The involvement of these pathways in mediating IGF actions in the placenta has yet to be determined, though they are implicated through studies of IUGR placentas which demonstrate abnormalities in IGF1R signalling [47].

MAPK Pathway

Abolition of MAPK by targeted gene disruption demonstrates that this intracellular signalling molecule is es- 
Fig. 2. Schematic diagram of IGF1R mediated signalling events. IGF-I or IGF-II (to lesser extent) bind to the IGF1R thereby inducing receptor autophosphorylation. This results in activation of PI3K and MAPK (ERK) pathways via a sequence of phosphorylation events resulting in transcription of target genes involved in promoting proliferation, survival and differentiation.

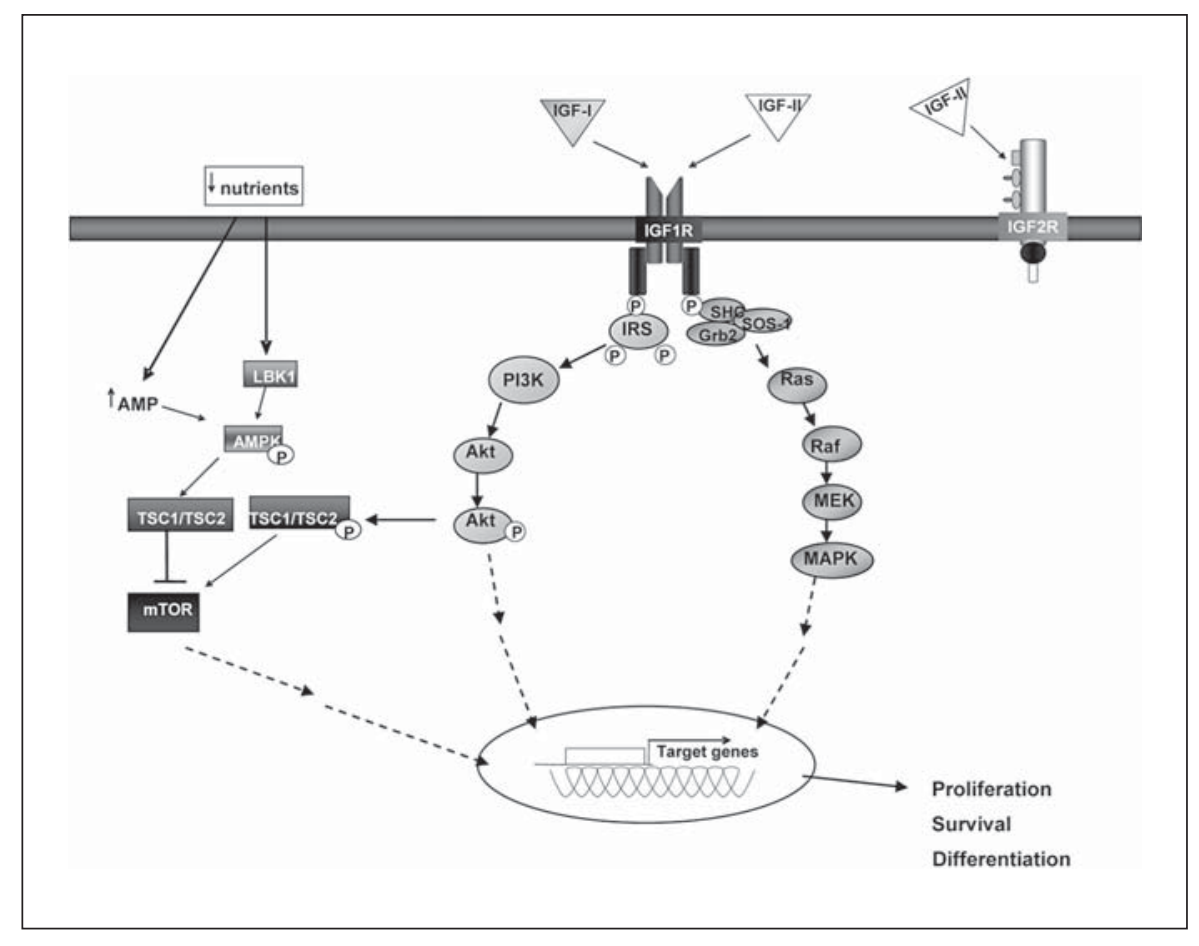

sential for normal placental development in mice [59]. In the human placenta, the MAPKs ERK1/2 are expressed in the villous trophoblast [60] and have been shown to regulate the differentiation of isolated primary cytotrophoblasts into syncytia [61]. Data demonstrating that activation of the MAPK pathway by receptor tyrosine kinases (e.g. EGFR and TGF- $\beta R$ ) induces invasion and migration in the placenta [62] suggests that activation of the MAPK signalling cascade may also be achieved by IGF1Rs. Interestingly, however, McKinnon et al. [57] report that in trophoblasts IGF-II activation of the MAPK pathway is achieved independently of the IGF1R via IGF2R stimulation of G-proteins.

\section{PI3K Pathway}

In other tissues, activated IGF1Rs recruit and phosphorylate IRS which leads to the activation of the PI3K/ Akt (also known as protein kinase B) pathway. In turn, Akt activates a phosphorylation cascade resulting in promotion of many cellular processes including cell survival. Akt has been reported to regulate rodent placental development and foetal growth [63], and in a dexamethasoneinduced murine model of IUGR, reduced levels of IGF-II are accompanied by a significant reduction in levels of phosphorylated Akt [64]. Further evidence to suggest that the PI3K pathway may be important in mediating
IGF signalling events in the placenta comes from recent studies involving the mammalian target of rapamycin (mTOR) pathway. mTOR has been found to be important in mediating IGF signalling events by acting downstream in the PI3K pathway; it can be activated by phosphorylated Akt to promote cell growth [65] or can be regulated by nutrient sensing signalling pathways (fig. 2). Since the mTOR pathway is important in mediating both nutrient and growth factor signals to promote cellular growth, it is likely that mTOR is also involved in regulating normal placental development. A recent study by Wen et al. [66] demonstrating that mTOR acts as a nutrient sensor to promote proliferation of immortalized human trophoblast cells supports this hypothesis; however, another group using the choriocarcinoma cell line BeWo have reported that the ability of IGF to regulate amino acid transport does not require $\mathrm{mTOR}$ [32]. It would therefore be interesting to see if mTOR is involved in IGF-mediated trophoblast events in primary placental cells or in explant cultures.

\section{Phosphatases}

In almost all cells, growth factor-induced activation of both PI3K and MAPK pathways is regulated by the protein tyrosine phosphatase, SHP-2 [67]. Evidence that SHP-2 may have a role in regulating signalling events in 
Table 2. Summary of the role of components of the IGF axis in the placenta: the role of IGFs and IGFBPs in promoting $(\uparrow)$ or inhibiting $(\downarrow)$ events in the placenta are described

\begin{tabular}{|c|c|c|}
\hline & Function & Authors, dates \\
\hline IGF-I & $\begin{array}{l}\uparrow \text { migration } \\
\uparrow \text { extravillous proliferation } \\
\uparrow \text { fibroblast proliferation } \\
\uparrow \text { differentiation } \rightarrow \text { syncytial } \\
\uparrow \text { differentiation } \rightarrow \text { extravillous } \\
\downarrow \text { apoptosis } \\
\text { metabolism: } \\
\uparrow \text { amino acid uptake }\end{array}$ & $\begin{array}{l}\text { Aplin et al., 2000; Lacey et al., } 2002 \\
\text { Maruo et al., 1995 } \\
\text { Miller et al., 2005 } \\
\text { Bhaumick et al., 1992; Milio et al., 1994; } \\
\text { Cohran et al., 1996 } \\
\text { Aplin et al., 2000; Lacey et al., } 2002 \\
\text { Smith et al., 2002; Miller et al., } 2005 \\
\text { Bloxam et al., 1994; Kniss et al., 1994; Karl et al., } \\
\text { 1995; Yu et al., 1998; Jensen et al., } 2000\end{array}$ \\
\hline IGF-II & $\begin{array}{l}\uparrow \text { migration } \\
\uparrow \text { extravillous proliferation } \\
\uparrow \text { cytotrophoblast proliferation } \\
\uparrow \text { fibroblast proliferation } \\
\downarrow \text { apoptosis } \\
\text { metabolism: } \\
\uparrow \text { nutrient exchange surface area } \\
\uparrow \text { permeability for nutrients }\end{array}$ & $\begin{array}{l}\text { Irving et al., 1995; Hamilton et al., } 1998 \\
\text { Thomsen et al., } 1997 \\
\text { Thomsen et al., } 1997 \\
\text { Miller et al., } 2005 \\
\text { Miller et al., } 2005 \\
\text { Lopez et al., 1996; Constancia et al., 2002; } \\
\text { Sibley et al., } 2004\end{array}$ \\
\hline IGFBP-1 & $\begin{array}{l}\downarrow \text { basal trophoblast migration } \\
\uparrow \text { basal trophoblast migration } \\
\uparrow \text { IGF-II induced trophoblast migration } \\
\downarrow \text { IGF- induced cytotrophoblast proliferation } \\
\downarrow \text { differentiation } \rightarrow \text { extravillous } \\
\text { metabolism: } \\
\text { np-IGFBP- } 1 \uparrow \text { IGF-I induced nutrient uptake } \\
\text { p-IGFBP- } 1 \downarrow \text { basal nutrient uptake } \\
\text { p-IGFBP- } 1 \downarrow \text { IGF-I induced nutrient uptake }\end{array}$ & $\begin{array}{l}\text { Irving et al., 1995; Hamilton et al., 1998; } \\
\text { Irwin et al., 1998; Gleeson et al., } 2001 \\
\text { Ritvos et al., } 1988 \\
\text { Crossey et al., 2002 } \\
\text { Ritvos et al., 1988; Yu et al., } 1998\end{array}$ \\
\hline IGFBP-3 & $\downarrow$ IGF-induced fibroblast proliferation & Rogers et al., 1996 \\
\hline
\end{tabular}

the placenta comes from studies on transgenic mice. When SHP-2 is truncated mice have severe developmental abnormalities and subsequently die at mid-gestation. More recently, it was reported that functional SHP-2 is required for murine trophoblast stem cell survival [68] and so it appears that SHP-2 may regulate foetal development by its actions on the placenta. In vascular smooth muscle cells SHP-2 positively regulates IGF signalling by interacting with IRS-1 and regulating IGF1R dephosphorylation [69] and therefore it may also be important to consider the role of SHP-2 in regulation of IGF-induced signalling events in the human placenta. Another phosphatase that appears to be involved in regulating placental development is MAPK phosphatase (MKP)-4. Transgenic mice which have a specific deletion of MKP-4 have abnormal placental development and all mice die in utero [70]. MKP-4 functions to regulate the activation of the MAPK pathway and since this pathway is integral for mediating signals from the IGF1R it is possible that this phosphatase may also function to regulate IGF-induced signalling events in the placenta.

\section{Conclusions}

We have reviewed the literature to demonstrate the importance of the IGF axis in regulating many aspects of placental development and the need to understand the signalling events by which IGFs exert their effects (table 2). By investigating the molecular mechanisms of IGF actions in the placenta, we will also gain a better understanding of how this complex system regulates the growth and development of other tissues and organs. It may also give us a better insight into how dysregulation of the IGF axis can result in disease progression. 


\section{References}

1 Le Roith D, Bondy C, Yakar S, Liu J-L, Butler A: The somatomedin hypothesis: 2001. Endocr Rev 2001;22:53-74.

$>2$ Sjogren K, Liu JL, Blad K, Skrtic S, Vidal O, Wallenius V, LeRoith D, Tornell J, Isaksson OG, Jansson JO, Ohlsson C: Liver-derived insulin-like growth factor I (IGF-I) is the principal source of IGF-I in blood but is not required for postnatal body growth in mice. Proc Natl Acad Sci USA 1999;96:7088-7092.

-3 Yakar S, Rosen CJ, Beamer WG, AckertBicknell CL, Wu Y, Liu JL, Ooi GT, Setser J, Frystyk J, Boisclair YR, LeRoith D: Circulating levels of IGF-1 directly regulate bone growth and density. J Clin Invest 2002;110: 771-781.

4 Jones JI, Clemmons DR: Insulin-like growth factors and their binding proteins: biological actions. Endocr Rev 1995;16:3-34.

$\checkmark 5$ Klauwer D, Blum WF, Hanitsch S, Rascher W, Lee PD, Kiess W: IGF-I, IGF-II, free IGFI and IGFBP-1, -2 and -3 levels in venous cord blood: relationship to birthweight, length and gestational age in healthy newborns. Acta Paediatr 1997;86:826-833.

6 Osorio M, Torres J, Moya F, Pezzullo J, Salafia C, Baxter R, Schwander J, Fant M: Insulin-like growth factors (IGFs) and IGF binding proteins-1, -2 , and -3 in newborn serum: relationships to fetoplacental growth at term. Early Hum Dev 1996;46:15-26.

7 Giudice LC, de Zegher F, Gargosky SE, Dsupin BA, de las Fuentes L, Crystal RA, Hintz $\mathrm{RL}$, Rosenfeld RG: Insulin-like growth factors and their binding proteins in the term and preterm human fetus and neonate with normal and extremes of intrauterine growth. J Clin Endocrinol Metab 1995;80:1548-1555.

$>8$ Efstratiadis A: Genetics of mouse growth. Int J Dev Biol 1998;42:955-976.

$\checkmark 9$ Watson CS, Bialek P, Anzo M, Khosravi J, Yee SP, Han VK: Elevated circulating insulin-like growth factor binding protein-1 is sufficient to cause fetal growth restriction. Endocrinology 2006;147:1175-1186.

$\checkmark 10$ Holmes R, Montemagno R, Jones J, Preece M, Rodeck C, Soothill P: Fetal and maternal plasma insulin-like growth factors and binding proteins in pregnancies with appropriate or retarded fetal growth. Early Hum Dev 1997;49:7-17.

-11 Modric T, Silha JV, Shi Z, Gui Y, Suwanichkul A, Durham SK, Powell DR, Murphy LJ: Phenotypic manifestations of insulin-like growth factor-binding protein-3 overexpression in transgenic mice. Endocrinology 2001; 142:1958-1967.

12 Walenkamp MJ, van der Kamp HJ, Pereira AM, Kant SG, van Duyvenvoorde HA, Kruithof MF, Breuning MH, Romijn JA, Karperien M, Wit JM: A variable degree of intrauterine and postnatal growth retardation in a family with a missense mutation in the insulin-like growth factor I receptor. J Clin Endocrinol Metab 2006;91:3062-3070.
13 Lau MM, Stewart CE, Liu Z, Bhatt H, Rotwein P, Stewart CL: Loss of the imprinted IGF2/cation-independent mannose 6-phosphate receptor results in fetal overgrowth and perinatal lethality. Genes Dev 1994;8: 2953-2963.

14 Sibley CP, Turner MA, Cetin I, Ayuk P, Boyd CA, D’Souza SW, Glazier JD, Greenwood SL, Jansson T, Powell T: Placental phenotypes of intrauterine growth. Pediatr Res 2005;58: $827-832$

$>15$ Baker J, Liu JP, Robertson EJ, Efstratiadis A: Role of insulin-like growth factors in embryonic and postnatal growth. Cell 1993;75:7382.

$>16$ Constancia M, Hemberger M, Hughes J, Dean W, Ferguson-Smith A, Fundele R, Stewart F, Kelsey G, Fowden A, Sibley C, Reik W: Placental-specific IGF-II is a major modulator of placental and fetal growth. Nature 2002;417:945-948.

$>17$ Kingdom J, Huppertz B, Seaward G, Kaufmann P: Development of the placental villous tree and its consequences for fetal growth. Eur J Obstet Gynecol Reprod Biol 2000;92:35-43.

18 Han VK, Bassett N, Walton J, Challis JR: The expression of insulin-like growth factor (IGF) and IGF-binding protein (IGFBP) genes in the human placenta and membranes: evidence for IGF-IGFBP interactions at the feto-maternal interface. J Clin Endocrinol Metab 1996;81:2680-2693.

19 Miller AG, Aplin JD, Westwood M: Adenovirally mediated expression of insulin-like growth factors enhances the function of first trimester placental fibroblasts. J Clin Endocrinol Metab 2005;90:379-385.

20 Smith S, Francis R, Guilbert L, Baker PN: Growth factor rescue of cytokine mediated trophoblast apoptosis. Placenta 2002;23: 322-330.

21 Irving JA, Lala PK: Functional role of cell surface integrins on human trophoblast cell migration: regulation by TGF-beta, IGF-II, and IGFBP-1. Exp Cell Res 1995;217:419427.

22 Hamilton GS, Lysiak JJ, Han VK, Lala PK: Autocrine-paracrine regulation of human trophoblast invasiveness by insulin-like growth factor (IGF)-II and IGF-binding protein (IGFBP)-1. Exp Cell Res 1998;244:147156.

23 Lacey H, Haigh T, Westwood M, Aplin JD: Mesenchymally-derived insulin-like growth factor 1 provides a paracrine stimulus for trophoblast migration. BMC Dev Biol 2002; 2:5.

24 Aplin JD, Lacey H, Haigh T, Jones CJ, Chen CP, Westwood M: Growth factor-extracellular matrix synergy in the control of trophoblast invasion. Biochem Soc Trans 2000;28: 199-202.
25 Qiu Q, Basak A, Mbikay M, Tsang BK, Gruslin A: Role of pro-IGF-II processing by proprotein convertase 4 in human placental development. Proc Natl Acad Sci USA 2005; 102:11047-11052.

-26 Bhaumick B, George D, Bala RM: Potentiation of epidermal growth factor-induced differentiation of cultured human placental cells by insulin-like growth factor-I. J Clin Endocrinol Metab 1992;74:1005-1011.

27 Milio LA, Hu J, Douglas GC: Binding of insulin-like growth factor I to human trophoblast cells during differentiation in vitro. Placenta 1994;15:641-651.

28 Sibley CP, Coan PM, Ferguson-Smith AC, Dean W, Hughes J, Smith P, Reik W, Burton GJ, Fowden AL, Constancia M: Placentalspecific insulin-like growth factor $2(\operatorname{Igf} 2)$ regulates the diffusional exchange characteristics of the mouse placenta. Proc Natl Acad Sci USA 2004; 101:8204-8208.

29 Constancia M, Angiolini E, Sandovici I, Smith P, Smith R, Kelsey G, Dean W, Ferguson-Smith A, Sibley CP, Reik W, Fowden A: Adaptation of nutrient supply to fetal demand in the mouse involves interaction between the Igf2 gene and placental transporter systems. Proc Natl Acad Sci USA 2005; 102:19219-19224.

30 Sferruzzi-Perri AN, Owens JA, Pringle KG, Robinson JS, Roberts CT: Maternal insulinlike growth factors-I and -II act via different pathways to promote fetal growth. Endocrinology 2006;147:3344-3355.

31 Karl PI: Insulin-like growth factor-1 stimulates amino acid uptake by the cultured human placental trophoblast. J Cell Physiol 1995; 165:83-88.

32 Fang J, Mao D, Smith CH, Fant ME: IGF regulation of neutral amino acid transport in the BeWo choriocarcinoma cell line (b30 clone): evidence for MAP kinase-dependent and MAP kinase-independent mechanisms. Growth Horm IGF Res 2006;16:318-325.

33 Sheikh S, Satoskar P, Bhartiya D: Expression of insulin-like growth factor-I and placental growth hormone mRNA in placentae: a comparison between normal and intrauterine growth retardation pregnancies. Mol Hum Reprod 2001;7:287-292.

34 Dalcik H, Yardimoglu M, Vural B, Dalcik C, Filiz S, Gonca S, Kokturk S, Ceylan S: Expression of insulin-like growth factor in the placenta of intrauterine growth-retarded human fetuses. Acta Histochem 2001;103:195207.

35 de Vrijer DEB, Davidsen ML, Wilkening RB, Anthony RV, Regnault TR: Altered placental and fetal expression of IGFs and IGF-binding proteins associated with intrauterine growth restriction in fetal sheep during early and mid-pregnancy. Pediatr Res 2006;60: 507-512. 
-36 Abu-Amero SN, Ali Z, Bennett P, Vaughan JI, Moore GE: Expression of the insulin-like growth factors and their receptors in term placentas: a comparison between normal and IUGR births. Mol Reprod Dev 1998;49: 229-235.

-37 Ong K, Kratzsch J, Kiess W, Costello M, Scott C, Dunger D: Size at birth and cord blood levels of insulin, insulin-like growth factor I (IGF-I), IGF-II, IGF-binding protein-1 (IGFBP-1), IGFBP-3, and the soluble IGF-II/ mannose-6-phosphate receptor in term human infants. The ALSPAC Study Team. Avon Longitudinal Study of Pregnancy and Childhood. J Clin Endocrinol Metab 2000; 85:4266-4269.

>38 Fang J, Furesz TC, Smith CH, Fant ME: IGF binding protein-1 (IGFBP-1) is preferentially associated with the fetal-facing basal surface of the syncytiotrophoblast in the human placenta. Growth Horm IGF Res 1999;9:438444.

-39 Irwin JC, Giudice LC: Insulin-like growth factor binding protein-1 binds to placental cytotrophoblast alpha5betal integrin and inhibits cytotrophoblast invasion into decidualized endometrial stromal cultures. Growth Horm IGF Res 1998;8:21-31.

40 Westwood M, Gibson JM, Davies AJ, Young RJ, White A: The phosphorylation pattern of insulin-like growth factor-binding protein-1 in normal plasma is different from that in amniotic fluid and changes during pregnancy. J Clin Endocrinol Metab 1994;79:17351741.

-41 Coppock HA, White A, Aplin JD, Westwood M: Matrix metalloprotease-3 and -9 proteolyze insulin-like growth factor-binding protein-1. Biol Reprod 2004;71:438-443.

-42 Yu J, Iwashita M, Kudo Y, Takeda Y: Phosphorylated insulin-like growth factor (IGF)binding protein-1 (IGFBP-1) inhibits while non-phosphorylated IGFBP-1 stimulates IGF-I-induced amino acid uptake by cultured trophoblast cells. Growth Horm IGF Res 1998;8:65-70.

$\checkmark 43$ Rogers J, Wiltrout L, Nanu L, Fant ME: Developmentally regulated expression of IGF binding protein-3 (IGFBP-3) in human placental fibroblasts: effect of exogenous IGFBP3 on IGF-1 action. Regul Pept 1996;61:189195.

44 Firth SM, Baxter RC: Cellular actions of the insulin-like growth factor binding proteins. Endocr Rev 2002;23:824-854.

45 Holmes R, Porter H, Newcomb P, Holly JM, Soothill P: An immunohistochemical study of type I insulin-like growth factor receptors in the placentae of pregnancies with appropriately grown or growth restricted fetuses. Placenta 1999;20:325-330.

-46 Fang J, Furesz TC, Lurent RS, Smith CH, Fant ME: Spatial polarization of insulin-like growth factor receptors on the human syncytiotrophoblast. Pediatr Res 1997;41:258265.
47 Laviola L, Perrini S, Belsanti G, Natalicchio A, Montrone C, Leonardini A, Vimercati A, Scioscia M, Selvaggi L, Giorgino R, Greco P, Giorgino F: Intrauterine growth restriction in humans is associated with abnormalities in placental insulin-like growth factor signaling. Endocrinology 2005;146:1498-1505.

48 Frasca F, Pandini G, Scalia P, Sciacca L, Mineo R, Costantino A, Goldfine ID, Belfiore A, Vigneri R: Insulin receptor isoform A, a newly recognized, high-affinity insulinlike growth factor II receptor in fetal and cancer cells. Mol Cell Biol 1999;19:32783288.

49 Reid GJ, Flozak AS, Simmons RA: Placental expression of insulin-like growth factor receptor-1 and insulin receptor in the growthrestricted fetal rat. J Soc Gynecol Investig 2002;9:210-214.

50 Diaz E, Cardenas M, Ariza AC, Larrea F, Halhali A: Placental insulin and insulin-like growth factor I receptors in normal and preeclamptic pregnancies. Clin Biochem 2005; 38:243-247.

51 Kasuya J, Paz IB, Maddux BA, Goldfine ID, Hefta SA, Fujita-Yamaguchi Y: Characterization of human placental insulin-like growth factor-I/insulin hybrid receptors by protein microsequencing and purification. Biochemistry 1993;32:13531-13536.

52 Federici M, Porzio O, Zucaro L, Fusco A, Borboni P, Lauro D, Sesti G: Distribution of insulin/insulin-like growth factor-I hybrid receptors in human tissues. Mol Cell Endocrinol 1997;129:121-126.

53 Soos MA, Field CE, Siddle K: Purified hybrid insulin/insulin-like growth factor-I receptors bind insulin-like growth factor-I, but not insulin, with high affinity. Biochem J 1993;290:419-426.

54 Slaaby R, Schaffer L, Lautrup-Larsen I, Andersen AS, Shaw AC, Mathiasen IS, Brandt J: Hybrid receptors formed by insulin receptor (IR) and insulin-like growth factor I receptor (IGF-IR) have low insulin and high IGF-1 affinity irrespective of the IR splice variant. J Biol Chem 2006;281:25869-25874.

55 Murayama Y, Okamoto T, Ogata E, Asano T, Iiri T, Katada T, Ui M, Grubb JH, Sly WS, Nishimoto I: Distinctive regulation of the functional linkage between the human cation-independent mannose 6-phosphate receptor and GTP-binding proteins by insulinlike growth factor II and mannose 6-phosphate. J Biol Chem 1990;265:17456-17462.

56 Zygmunt M, McKinnon T, Herr F, Lala PK, Han VK: HCG increases trophoblast migration in vitro via the insulin-like growth factor-II/mannose- 6 phosphate receptor. $\mathrm{Mol}$ Hum Reprod 2005;11:261-267.

57 McKinnon T, Chakraborty C, Gleeson LM, Chidiac P, Lala PK: Stimulation of human extravillous trophoblast migration by IGF-II is mediated by IGF type 2 receptor involving inhibitory $\mathrm{G}$ protein(s) and phosphorylation of MAPK. J Clin Endocrinol Metab 2001;86: 3665-3674.
58 Vincent AM, Feldman EL: Control of cell survival by IGF signaling pathways. Growth Horm IGF Res 2002;12:193-197.

59 Hatano N, Mori Y, Oh-hora M, Kosugi A, Fujikawa T, Nakai N, Niwa H, Miyazaki J, Hamaoka T, Ogata M: Essential role for ERK2 mitogen-activated protein kinase in placental development. Genes Cells 2003;8: 847-856.

60 Kita N, Mitsushita J, Ohira S, Takagi Y, Ashida T, Kanai M, Nikaido T, Konishi I: Expression and activation of MAP kinases, ERK1/2, in the human villous trophoblasts. Placenta 2003;24:164-172.

61 Daoud G, Amyot M, Rassart E, Masse A, Simoneau L, Lafond J: ERK1/2 and p38 regulate trophoblasts differentiation in human term placenta. J Physiol 2005;566:409-423.

62 Qian D, Lin HY, Wang HM, Zhang X, Liu DL, Li QL, Zhu C: Involvement of ERK1/2 pathway in TGF-beta1-induced VEGF secretion in normal human cytotrophoblast cells. Mol Reprod Dev 2004;68:198-204.

63 Yang ZZ, Tschopp O, Hemmings-Mieszczak M, Feng J, Brodbeck D, Perentes E, Hemmings BA: Protein kinase B alpha/Akt1 regulates placental development and fetal growth. J Biol Chem 2003;278:32124-32131.

64 Ain R, Canham LN, Soares MJ: Dexamethasone-induced intrauterine growth restriction impacts the placental prolactin family, insulin-like growth factor-II and the Akt signaling pathway. J Endocrinol 2005;185: 253-263.

-65 Levine AJ, Feng Z, Mak TW, You H, Jin S: Coordination and communication between the p53 and IGF-1-AKT-TOR signal transduction pathways. Genes Dev 2006;20:267275 .

66 Wen HY, Abbasi S, Kellems RE, Xia Y: mTOR: a placental growth signaling sensor. Placenta 2005;26(suppl A):S63-S69.

-67 Qu CK: Role of the SHP-2 tyrosine phosphatase in cytokine-induced signaling and cellular response. Biochim Biophys Acta 2002; 1592:297-301.

-68 Yang W, Klaman LD, Chen B, Araki T, Harada $\mathrm{H}$, Thomas $\mathrm{SM}$, George EL, Neel BG: An Shp2/SFK/Ras/Erk signaling pathway controls trophoblast stem cell survival. Dev Cell 2006;10:317-327.

-69 Maile LA, Clemmons DR: Regulation of insulin-like growth factor I receptor dephosphorylation by SHPS-1 and the tyrosine phosphatase SHP-2. J Biol Chem 2002;277: 8955-8960.

70 Christie GR, Williams DJ, MacIsaac F, Dickinson RJ, Rosewell I, Keyse SM: The dualspecificity protein phosphatase DUSP9/ MKP-4 is essential for placental function but is not required for normal embryonic development. Mol Cell Biol 2005;25:8323-8333. 